\section{(C) OPEN ACCESS}

\title{
Pyromellitic dianhydride (PMDA) may cause occupational asthma
}

\author{
Milene Torp Madsen, ${ }^{1}$ Lars Rauff Skadhauge, ${ }^{2}$ Anders Daldorph Nielsen, ${ }^{1}$ \\ Jesper Baelum, ${ }^{1}$ David Lee Sherson ${ }^{1,3}$
}

'Department of Occupational and Environmental Medicine, Odense University Hospital, Odense, Denmark

${ }^{2}$ Department of Occupational Medicine, Hospital of South West Jutland, Esbjerg, Denmark ${ }^{3}$ Department of Pulmonary Medicine, Odense University Hospital, Odense, Denmark

Correspondence to Dr Milene Torp Madsen, Department of Occupational and Environmental Medicine, Odense University Hospital, Odense 5230, Denmark; milene.t.madsen@rsyd.dk

Received 28 June 2018 Revised 13 November 2018 Accepted 9 December 2018 Published Online First 11 January 2019

\section{Check for updates}

(c) Author(s) (or their employer(s)) 2019. Re-use permitted under CC BY-NC. No commercial re-use. See rights and permissions. Published by BMJ.

To cite: Madsen MT, Skadhauge LR, Nielsen AD, et al. Occup Environ Med 2019;76:175-177.

\section{ABSTRACT}

Introduction Anhydrides are widely used as cross-linking agents in epoxy resins and alkyd production, for example, as coatings and adhesives in plastic products. Sensitisation to several anhydrides is known to cause occupational asthma. There are indications that the lesser known pyromellitic dianhydride (PMDA) can cause irritative respiratory symptoms and possibly asthma. We report three cases of workers from a plastic foil manufacturing plant, who developed asthma when exposed to PMDA during specific inhalation challenge (SIC).

Methods SIC was performed over 2 days according to recommendations of European Respiratory Society. Lactose powder was used in control challenges and a mixture of 10\% PMDA and 90\% lactose powder in active challenges. Results All cases experienced a delayed decrease in forced expiratory flow in $1 \mathrm{~s}\left(\mathrm{FEV}_{1}\right)$ 4-12 hours after active challenge. FEV decreased by $19 \%, 15 \%$ and $16 \%$, respectively. After 21 hours, FEV decreased by $24 \%$ in one worker.

Discussion Respiratory symptoms after working hours may represent delayed work-related asthma. During SIC, the three patients developed lower respiratory symptoms and a delayed decrease in FEV, which suggest sensitisation. The mechanism of anhydride-related asthma is not well understood. Anhydrides are known irritants and hence an irritative response cannot be excluded. The company improved ventilation and enforced the use of respiratory protection equipment, and finally phased out PMDA. Occupational workplace risk identification may help to identify exposures. SIC can contribute to improving working conditions, by identifying and confirming asthmogens in the environment.

\section{INTRODUCTION}

Pyromellitic dianhydride (PMDA) is one of several highly reactive acid anhydrides and used extensively in the production of thermoplastics and high-performance coatings. ${ }^{12}$ Anhydrides including PMDA are respiratory irritants and immediate-type sensitisers. ${ }^{3}$ Some anhydrides have been associated with occupational asthma. ${ }^{134}$ PMDA has also been related to occupational asthma. ${ }^{135-8}$ This short report presents three cases where asthma due to PMDA exposure is suggested.

Three workers in a plastic foil manufacturing plant were referred to the Department of Occupational Medicine due to work-related respiratory symptoms. Case A was a 52-year-old ex-smoking male maintenance worker with no previous respiratory symptoms. He had worked for 16 years at
Key messages

What is already known about this subject?

- Pyromellitic dianhydride (PMDA) is one of several highly reactive acid anhydrides.

- Exposure to acid anhydrides is known to cause skin irritation, mucous reactions and asthma.

What are the new findings?

- We report three cases with persistent asthmatic symptoms associated with PMDA exposure. Specific inhalation challenge (SIC) suggests PMDA as an asthmogen in all three cases.

- SIC is considered the reference method for diagnosing asthma caused by low-molecularweight substances.

How might this impact on policy or clinical practice in the foreseeable future?

- Clinicians diagnosing and treating patients with asthma should be aware of possible work exposure to PMDA. The present cases demonstrate the importance of considering asthma after work as possible delayed workrelated asthma.

- SIC may be useful in confirming causal factors and improving the work environment associated with work-related asthma.

the plant. Case B was a 46-year-old non-smoking male operator, working for 4 years with control and monitoring of the extrusion process. He had no previous respiratory symptoms. Case $\mathrm{C}$ was a 46-year-old non-smoking male electrician, who had atopic dermatitis and hay fever as a child. He was employed for 24 years.

PMDA had been used at the plant since 2008, to increase the viscosity of plastic food packaging products used in the food industry. Initially, PMDA powder was poured directly in a funnel from $10 \mathrm{~kg}$ bags. After a few years, the PMDA bags were opened and added in industrial glove boxes to reduce dust exposure.

In 2014, the company introduced a new larger extruder, where PMDA was added in a semiopen dosing system several metres above the main working area. In the spring of 2015, local exhaust ventilation in the new extruder was closed for repairs. Three employees developed respiratory symptoms within a few months after the new extruder was introduced, particularly when 
changing filters and during reparations. Respiratory protective equipment was occasionally used during these work processes.

\section{METHODS}

Initial risk identification was performed during workplace visits. Clinical histories focused on individual and occupational risk factors. Serial peak expiratory flow measurements were registered during work and weekends. Medical examinations included chest X-ray and spirometry using an EasyOne Spirometer (ndd Medical Technologies, Andover, Massachusetts, USA). Methacholine Challenge Test was performed according to standardised procedures, delivered from a nebuliser (Jaeger APS-system) by breath-activated dosimeter method in increasing dosages. ${ }^{9}$ The response to methacholine is measured as the provocation dose that results in a $20 \%$ fall in forced expiratory flow in $1 \mathrm{~s}\left(\mathrm{FEV}_{1}\right)$ compared with baseline $\mathrm{FEV}_{1}\left(\mathrm{PD}_{20}\right.$ methacholine)

Specific immunoglobulin (Ig) E to common aeroallergens and available anhydrides were measured using kits from ThermoFisher.

\section{Specific inhalation challenge (SIC)}

SIC was performed according to the recommendations of the European Respiratory Society. ${ }^{10}$ Asthma treatment was carefully reduced before the challenge. SIC was performed in a $7 \mathrm{~m}^{3}$ challenge chamber at the outpatient asthma clinic, Odense University Hospital. Temperature, $\mathrm{CO}_{2}$, humidity, air exchange and dust particles (DustTrak ${ }^{\mathrm{R}}$, TSI, Shoreview, Minnesota, USA) were monitored. Day 1: control challenge with lactose powder. Day 2: active challenge, with pouring $200 \mathrm{~g}$ powder $(90 \%$ lactose and $10 \%$ PMDA) back and forth between two trays. Dust levels were between 0.8 and $3.0 \mathrm{mg} / \mathrm{m}^{3}$. The active challenge was followed by hospitalisation at the Pulmonary Department. FEV 1 was registered frequently the first hour and every hour in the additional 10-14 hours thereafter.

\section{RESULTS}

There were no PMDA air measurements from the workplace. Clinical characteristics of the three cases and their responses to SIC are summarised in table 1 . Pre-SIC spirometry showed FEV of $88 \%, 69 \%$ and $106 \%$ of predicted values, respectively. Case A had positive specific IgE for three of the five anhydrides. The two other cases had elevated specific IgE for various common aeroallergens. During PMDA challenge, FEV fell 19\%, 15\% and $16 \%$ after 6 to 12 hours (see figure 1 ). After 21 hours, FEV fell by $24 \%$ in case B. Termination of PMDA exposure at the plastic foil manufacturing plant resulted in symptoms reduction and in two cases significant improvement in lung function.

\section{DISCUSSION}

The present results suggest that PMDA exposure may cause occupational asthma. Various anhydrides have been associated with asthma. ${ }^{12411}$ PMDA has also been linked to rhinitis, haemorrhagic rhinitis and bronchial hyper-responsiveness. ${ }^{35-8} \mathrm{~A}$ limited number of PMDA-related asthma symptoms have been described. A Japanese group reported two possible cases of occupational asthma caused by PMDA. ${ }^{7}$ A study with workplace challenges demonstrated asthma in one worker after mixing epoxy and PMDA. It was unknown which component was asthmogentic. ${ }^{6}$ Two studies using airway resistance identified four cases of PMDA-related asthma. ${ }^{5}$ The more common fall in $\mathrm{FEV}_{1}$ was not used in these studies.
Table 1 Clinical characteristics and response to SIC

\begin{tabular}{|c|c|c|c|}
\hline Case & A & B & C \\
\hline Respiratory symptoms & Lower & $\begin{array}{l}\text { Upper and } \\
\text { lower }\end{array}$ & Lower \\
\hline Total lgE, kU/L & 24 & 383 & 664 \\
\hline Eosinophils, $10^{9} / \mathrm{L}$ & 0.07 & 0.25 & 0.16 \\
\hline Specific $\lg \mathrm{E}$, anhydrides & Positive * & Negative & Negative \\
\hline Specific IgE, aeroallergens & Negative & Positivet & Positiveł \\
\hline $\begin{array}{l}\text { Baseline } \mathrm{FEV}_{1}, \mathrm{~L},(\% \text { of predicted } \\
\text { values), } \mathrm{FEV}_{1} / \mathrm{FVC}\end{array}$ & $\begin{array}{l}3.31(88 \%), \\
0.52\end{array}$ & $\begin{array}{l}2.41(69 \%), \\
0.74\end{array}$ & $\begin{array}{l}3.90(106 \%) \\
0.75\end{array}$ \\
\hline Peakflow diurnal variability & $20 \%$ & $16 \%$ & Not tested \\
\hline $\begin{array}{l}\text { Methacholine Challenge Test }\left(\mathrm{PD}_{20}\right) \text {, } \\
\mu \mathrm{g} \S\end{array}$ & 268 & Negative & 261 \\
\hline $\begin{array}{l}\text { Maximum fall in } \mathrm{FEV}_{1} \text { /hours from } \\
\text { challenge start }\end{array}$ & $19 \% / 4$ & $\begin{array}{l}16 \% / 12 \\
24 \% / 24\end{array}$ & $17 \% / 9$ \\
\hline Respiratory symptoms during SIC & Lower & Lower & Lower \\
\hline
\end{tabular}

${ }^{*}$ Phthalic anhydride, hexahydrophthalic anhydride, methyltetrahydrophtalic anhydride, positive $>0.1 \mathrm{kU} / \mathrm{L}$.

tPhleum pratensa, Dermatophagoides farinae, Dermatophagoides pteronyssinus, positive $>0.35 \mathrm{kU} / \mathrm{L}$.

$\ddagger$ Phleum pratensa, Betula verrucosa, Artemisia vulgaris, Cladosporium herbarium , positive $>0.35 \mathrm{kU} / \mathrm{L}$

§Dose of metacholine that results in a $20 \%$ fall in $\mathrm{FEV}_{1}$, positive $<400 \mu \mathrm{g}$. $\mathrm{FEV}_{1}$, forced expiratory flow in $1 \mathrm{~s}$; IgE, immunoglobulin $\mathrm{E} ; \mathrm{SIC}$, specific inhalation challenge.

The mechanisms of anhydride-related asthma are not well understood. ${ }^{12}$ Some individuals with asthma caused by anhydrides show specific IgE antibodies to anhydride-human serum albumin conjugates suggesting IgE mediation. ${ }^{8} 1112$ Cross-reactivity among anhydrides has been shown. ${ }^{8}$ No commercial kits analysing specific IgE to PMDA are available. Only one of the three cases had positive specific IgE to the available anhydrides suggesting possible sensitisation. Thus, cross-reactivity with other anhydrides was not useful in these cases. During SIC, the three patients developed lower respiratory symptoms and delayed fall in $\mathrm{FEV}_{1}$ suggesting sensitisation.

Anhydrides are also highly irritative. ${ }^{2-4}$ The absence of upper respiratory symptoms during SIC argues against an irritant reaction. Furthermore, the exposure levels during SIC were below the occupational exposure limit value for anhydrides in Denmark of $0.4 \mathrm{mg} / \mathrm{m}^{3}$ (Maleic anhydride). Thus,

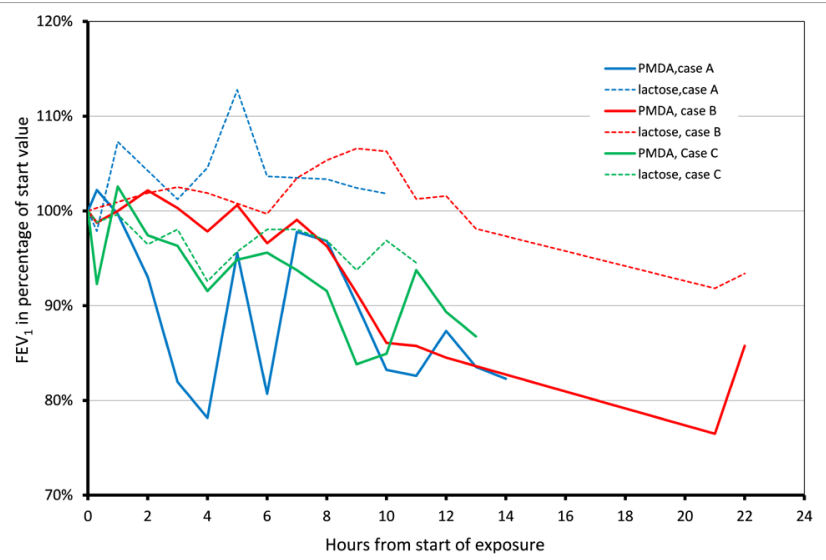

Figure 1 Change of $\mathrm{FEV}_{1}$ in per cent of baseline values during control and PMDA challenge. FEV , forced expiratory flow in $1 \mathrm{~s}$; PMDA, pyromellitic dianhydride. 
an irritative response is less likely. Finally, the delayed asthma resulted from the challenges, further suggest an immunological response.

Due to these results the company expanded the use of respirators and improved ventilation. Finally, the use of PMDA was completely eliminated at the plant. Asthma symptoms were reduced in all three cases after PMDA was eliminated. Two had marked improvement with normalisation of lung function. Lung function was not improved in case B, suggesting that PMDA-associated asthma may be persistent.

SIC is useful in diagnosing occupational asthma due to LMW agents. LMW-associated asthma is often delayed ${ }^{1}$ and can be identified by SIC. Thus, symptoms after work may be work-related. Correctly diagnosing work-related asthma can be very useful in improving work environments.

Contributors DLS, LRS and JB: identified the cases. DLS, LRS, JB, ADN and MTM: managed the cases. DLS, LRS and JB: examined the cases. DLS: had the idea for the article. MTM, DS, LRS and JB: reported the work described in this article. DLS and LRS: are guarantors of this Short Report.

Funding The authors have not declared a specific grant for this research from any funding agency in the public, commercial or not-for-profit sectors.

Competing interests None declared.

Patient consent Obtained.

Provenance and peer review Not commissioned; externally peer reviewed.

Open access This is an open access article distributed in accordance with the Creative Commons Attribution Non Commercial (CC BY-NC 4.0) license, which permits others to distribute, remix, adapt, build upon this work non-commercially, and license their derivative works on different terms, provided the original work is properly cited, appropriate credit is given, any changes made indicated, and the use is non-commercial. See: http://creativecommons.org/licenses/by-nc/4.0/.

\section{REFERENCES}

1 Zeiss CR. Advances in acid anhydride induced occupational asthma. Curr Opin Allergy Clin Immunol 2002:2:89-92.

2 Zeiss CR. Reactive chemicals in industrial asthma. J Allergy Clin Immunol 1991;87:755-61.

3 Baur X, Czuppon AB, Rauluk I, et al. A clinical and immunological study on 92 workers occupationally exposed to anhydrides. Int Arch Occup Environ Health 1995:67:395-403.

4 Nielsen J, Welinder H, Bensryd I, et al. Ocular and airway symptoms related to organic acid anhydride exposure--a prospective study. Allergy 2006:61:743-9.

5 Baur X. Asthmatic reactions after nasal allergen provocation. Respiration 1996;63:84-7

6 Meadway J. Asthma and atopy in workers with an epoxy adhesive. Br J Dis Chest 1980:74:149-54

7 Tanaka K. [Two cases of occupational asthma probably caused by pyromellitic anhydride]. Sangyo Igaku 1992;34:150-1.

8 Baur X, Czuppon A. Diagnostic validation of specific lgE antibody concentrations, skin prick testing, and challenge tests in chemical workers with symptoms of sensitivity to different anhydrides. J Allergy Clin Immunol 1995;96:489-94.

9 Crapo RO, Casaburi R, Coates AL, et al. Guidelines for methacholine and exercise challenge testing-1999. This official statement of the American Thoracic Society was adopted by the ATS Board of Directors, July 1999. Am J Respir Crit Care Med 2000;161:309-29.

10 Vandenplas 0 , Suojalehto $\mathrm{H}$, Aasen TB, et al. Specific inhalation challenge in the diagnosis of occupational asthma: consensus statement. Eur Respir J 2014;43:1573-87.

11 Barker RD, van Tongeren MJ, Harris JM, et al. Risk factors for bronchial hyperresponsiveness in workers exposed to acid anhydrides. Eur Respir J 2000;15:710-5.

12 Czuppon AB, Merget R, Raulf-Heimsoth M, et al. Comparison of IgE antibody concentrations to pyromellitic dianhydride-modified laminin and human serum albumin in sera of exposed workers with respiratory complaints. Int Arch Allergy Immunol 2002;127:79-81. 